\title{
ERRATUM
}

\section{Coding cerebral bypasses: a proposed nomenclature to better describe bypass constructs and revascularization techniques}

TO THE READERSHIP: An error appeared in the article by Tayebi Meybodi et al. (Tayebi Meybodi A, Gadhiya A, Borba Moreira L, et al. Coding cerebral bypasses: a proposed nomenclature to better describe bypass constructs and revascularization techniques. J Neurosurg. Published online July 2, 2021. doi:10.3171/2020.9.JNS202362).

Arjun Gadhiya's surname was misspelled. It appears correctly in the author listing below and has been updated in the Author Contributions section.

Ali Tayebi Meybodi, MD, ,,2 Arjun Gadhiya,

MBBS, ${ }^{2}$ Leandro Borba Moreira, MD, ${ }^{1}$ and

Michael T. Lawton, $\mathrm{MD}^{1}$ 2021.

The article has been corrected online as of October 1,

Michael T. Lawton, MD

Barrow Neurological Institute, St. Joseph's Hospital and Medical Center,

Phoenix, AZ

CORRESPONDING ARTICLE See pp 163-174.

INCLUDE WHEN CITING

Published online October 1, 2021; DOI: 10.3171/2021.8.JNS202362a.

CAANS 2022, except where prohibited by US copyright law 